\title{
Intrinsic Atopic Dermatitis: Titration of Precipitins in the Screening of Food Allergens for Prescription of Elimination Diets and Desensitization Strategies
}

\author{
Celso E. Olivier, Daiana G. Pinto, Ana P. M. Teixeira, Jhéssica L. S. Santana, \\ Raquel A. P. G. Santos, and Regiane P. S. Lima
}

ABSTRACT

Background: The diagnosis of non-IgE mediated food allergies may be a complex puzzle when there is no start point to establish an elimination diet to allow a clear clinical field to initiate diagnostic Oral Food Challenges tests.

Objective: To evaluate the opportunity of the tube titration of precipitins to select food allergens to proceed with elimination diets to assist the diagnosis and management of adult patients with Food Allergy manifested as Intrinsic Atopic Dermatitis (IAD).

Methods: The tube titration of specific precipitins against anamnesischosen food allergens were performed in 64 IAD patients and their titers were associated with an Improvement Verbal Scale Rate (IVSR) of the patient's perception of the benefits of the Precipitins-based Elimination Diet (PED) performed with these specific food allergens, as well correlated with their positive or negative perception of the impairment of symptoms after the reintroduction of the Symptom-Related Food Allergen (SRFA).

Results: In most cases, the PED contributed to a significant clinical improvement that allowed the patients to evaluate the individual effect of the reintroduction of each food allergen on their diets. There was a significant positive correlation coefficient between the titers of the foodspecific titration of precipitins and the percentage of positive SRFA (Pearson $r=0.91$; p-value $=0.0004$ ).

Conclusion: The semiquantitative titration of specific precipitins against food allergens is a promising triage test to select food allergens to proceed with elimination diets to support the diagnosis and management of nonIgE mediated Food Allergy in patients with Intrinsic Atopic Dermatitis.

Keywords: Allergy, antigen-antibody complex, atopic dermatitis, diet therapy, immune complex diseases, immunoassay, hypersensitivity, precipitins, precipitins tests.

Published Online: November 16, 2021

ISSN: $2736-5476$

DOI: $10.24018 /$ ejclinicmed.2021.2.6.129

\section{E. Olivier*}

Instituto Alergoimuno de Americana, Brasil.

(e-mail: celso@alergoimuno.med.br)

D. G. Pinto

Instituto Alergoimuno de Americana, Brasil.

(e-mail: daianaguedes85@gmail.com)

A. P. M. Teixeira

Instituto Alergoimuno de Americana, Brasil.g

(e-mail: monezzi88@gmail.com)

J. L. S. Santana

Instituto Alergoimuno de Americana, Brasil.

(e-mail: ljhessica31@gmail.com)

R. A. P. G. Santos

Instituto Alergoimuno de Americana, Brasil.

(e-mail: raquel.cuidados@gmail.com)

R. P. S. Lima

Instituto Alergoimuno de Americana, Brasil.

(e-mail: regianepatussi@gmail.com)

*Corresponding Author

\section{INTRODUCTION}

Atopic Dermatitis (AD) is a broad diagnostic designation for a group of heterogeneous diseases whose common denominator is a chronic dermal inflammation produced by some kind of immune hypersensitivity against at least one exogenous agent [1]. Dermal inflammation is not an exclusivity of $\mathrm{AD}$, since it may be produced by a myriad of pathogenic conditions (auto-immune diseases, tumoral diseases, infectious diseases, chemical contact aggressors, et cetera). When associating the term "atopic" to the diagnosis of "dermatitis", the assistant physician must have in mind that there is, at least, one mechanism of hypersensitivity against, at least, one external cause, which ideally should be demonstrated [2]. AD is a multifaceted condition with multifactorial pathophysiology involving diversified innate and adaptive immune mechanisms, employing humoral- and cell-mediated inflammatory hypersensitivity, triggered by food allergens, aeroallergens, contact allergens, and toxins produced by skin microbiome, parasitic fungi, and house dust mites [3], [4]. Also called atopic eczema, the AD syndrome covers different phenotypes and endotypes, according to the clinical presentation and underlying molecular mechanisms, some of them linked to psoriasis, that, now a day has also been considered an endotype presentation of $\mathrm{AD}$ [5], [6]. Genetic susceptibility determines the diversified expression of $\mathrm{AD}$, as pure or mixed with concomitant respiratory or digestive allergy, which also advocates against the simplified dermatologic management still largely used, justifying a causal investigation and a tailored personalized treatment derived from Precision Medicine [7]-[10]. Instead of one distinct skin disease, $\mathrm{AD}$ is better appreciated as the skin compartmentalization of a systemic hypersensitivity 
condition, which fundaments its treatment with systemic approaches such as oral/sublingual allergen-specific immunotherapy, currently used to treat allergic patients presenting respiratory, gastrointestinal or dermatologic symptoms [11]-[13]. The main subdivision of $\mathrm{AD}$ is established according to the IgE status i.e., the "intrinsic" (not mediated by $\operatorname{IgE}$ ) and "extrinsic" (IgE-mediated), however, patients with IgE-mediated mechanisms may also present, concomitantly, a non-IgE mediated hypersensitivity mechanism [14]-[16]. The non-IgE mediated IAD represents just $20 \%$ of the AD cases but introduces a diagnostic dilemma for the physician [17], [18]. Intrinsic Atopic Dermatitis (IAD) presents relatively late-onset and milder severity than the extrinsic phenotype. Perturbation of the skin barrier and filaggrin mutations are features of Extrinsic AD, but not IAD, which is better immunological characterized by the lower expression of IL-4; IL-5, and IL-13 and higher expression of interferon-gamma [14]. The sensitivity of the skin is relatively lower in IAD than in the extrinsic endotype, which correlates with systemic disease severity markers, but not with skin barrier impairment [19]. Hypersensitivity reactions are usually recognized to be elicited by adaptive immune responses i.e., mediated by lymphocytes and antibodies, but the innate system is an essential part of the inflammatory process. In the course of the clinical investigation of $\mathrm{AD}$ patients, usually, the immunologist works to identify, according to the four types of hypersensitivity reactions reported by Gell and Coombs, the particular mechanism(s) responsible for the production of the symptoms. The undetectability of specific IgE against a comprehensive battery of most common allergens usually discards the Gell and Coombs' type I hypersensitivity reaction and defines the IAD. The so-called Gell and Coombs' type II hypersensitivity reactions include a wide variety of immune mechanisms that possess in common the participation of immune cells and IgG and/or IgM antibodies. The Gell and Coombs' type III hypersensitivity reaction may produce lymphocytic infiltrates and circulating immune complexes. The Gell and Coombs' type IV hypersensitivity reaction is a contact dermatitis produced by the interaction of cytotoxic $\mathrm{T}$ lymphocytes and macrophages and may produce dermal lymphohistiocytic infiltrates [20], [21]. Hypersensitivity to food allergens, food additives, and/or food contaminants is one of the main causes of IAD [22]-[24]. The high diversity of possibilities of causative agents able to produce IAD turns the definition of the etiologic diagnosis into a real challenge to the assistant physician. Mostly, in non-immediate, non-IgE mediated allergic reactions, it is hard or almost impossible to indict culprits through anamnesis, especially in polysensitized patients [25], [26]. In these cases, the diagnosis of non- $\operatorname{IgE}$ mediated food allergies depends on in vivo Oral Food Challenge tests (OFC) [27]. However, before initiating the $\mathrm{OFC}$, the patients must be engaged in an efficient exclusion diet that eliminates their symptoms [28]-[31]. The OFC is also impracticable when the patient is unable to discontinue the use of antihistamines and steroids. Additionally, the OFC is, traditionally, a suitable technique to discriminate immediate reactions, such as the occurring in patients with acute urticaria, and technically inoperable when the symptoms are insidious, dependent of high thresholds, and/or take several days to appear and weeks to disappear. So, it is a common medical practice to suggest empirically based elimination diets during 4 to 8 weeks to the management of patients with suspected non-IgE mediated food allergies [32], [33]. However, some colleagues, instead of using an empirically based strategy, reported an IgG-based approach to propose elimination diets to manage, with variable success, non-IgE mediated hypersensitivity syndromes [34]. Motivated by these perspectives, and by our own previous experience with precipitin's titration for the screening of nonIgE mediated acute urticaria, we begun to study the opportunity of the use of food-specific precipitins as a tool to the management of patients with IAD. Since it is hard to differentiate the particular participation of the individual measures in the long-term management of non-immediate hypersensitivity disease; adding the fact that the management of IAD involves a combination of personalized therapeutic prescriptions (such as the skin moistening, the treatment of occasional infections, the avoidance of concomitant chemical and biological irritants, for instance), we proposed a proofof-concept study to evaluate the feasibility of the foodspecific precipitation titration in a medium-term experience.

\section{METHODS}

\section{A. Subjects}

The study was designed to characterize the utility of the titration of food-specific precipitins as an aid to indicate suspected food allergens, to proceed with diagnostic and therapeutic elimination diets for management of non-IgE mediated food allergies in adults with clinical features of IAD [35]. After receiving institutional review board approval, we selected a group of patients with these characteristics:

A) Clinical diagnosis of moderate to severe IAD, with more than $10 \%$ of affected body surface, with at least three years of evolution.

B) Non-reagent allergic skin scrape tests done with airborne, microbial, and food allergens [36].

C) Normal-range total IgE and non-detectable specific-IgE against airborne, microbial, and food allergens.

D) Negative history of anaphylactic reactions to food allergens.

We invited, with informed consent formularies, 64 outpatients (17 male; $20-90$ years; mean age 52,7 years; SD 19,1 years) with the above-mentioned characteristics, to voluntarily provide blood samples to perform in vitro foodspecific precipitation titrations, according to the principles of the World Medical Association Declaration of Helsinki and the International Committee of Medical Journals Editors requirements of privacy [37]. After a throughout nutritional anamnesis, we choose, with the patient's accordance, a personalized group of three to eight suspected food allergens, which were regularly consumed by them. The patients' blood was collected to perform the precipitin's titration against these food allergens and the patients were stimulated to engage an elimination diet based on the precipitin's titers: the Precipitin-based Elimination Diet (PED). After at least four weeks of effective PED, the patients were invited to return and describe, in their own words, their perception of the influence of the PED on the improvement of the symptoms, especially the pruritus. During the evaluation, they were 
stimulated to graduate according to an Improvement Verbal Rating Scale (IVSR) a tenfold percentage (0-100\%) describing their subjective perception of the benefits of the PED on the improvement of their symptoms, especially pruritus [38], [39]. After this, the unmedicated patients were oriented to re-introduce during a whole week, successively and non-concomitantly, each suspected food allergen that had participated in the PED. The patients were oriented to return for re-evaluation and describe, to each re-introduced food, a positive or negative association with the subjective impairment of their symptoms. The food allergens were recorded as "positive" or "negative" Symptom-Related Food Allergen (SRFA) and their percentages were correlated with the corresponding precipitins' titer: the highest dilution factor that yielded a positive precipitation reading.

\section{B. Food Antigens Preparation}

Food antigens for the cutaneous and in vitro challenge tests were bought at a local marketplace, extracted, and purified at our laboratory. The raw food allergens were extracted in Coca's solution at $4{ }^{\circ} \mathrm{C}$ for 24 hours, before centrifugation and separation of the water-soluble fraction from solid particles and oily fraction [40]. The protein quantification of the allergen extracts was done according to Bradford's protein-dye binding methodology [41]. All allergen extracts were diluted to an estimated protein concentration of 1 $\mathrm{mg} / \mathrm{mL}$ and stored at $4{ }^{\circ} \mathrm{C}$. The food allergens studied by allergic skin scrape tests and precipitin's titration were Brazil nut, banana, bovine meat, chicken meat, cocoa, cow's milk, egg's white, egg's yolk, tilapia, garlic, gluten, latex-related food (or Hevea brasiliensis latex for skin and blood tests), nut, onion, orange, peanut, pecan nut, red bean, red pepper, rice, shrimp, soybean, swine meat, tomato, and bread/beer Saccharomyces cerevisiae yeast. The total number of pairs of tests was 312. When the anamnesis revealed a suspicion of allergy against more than one latex-related food, the precipitin's tests were done with the Hevea brasiliensis latex. When the suspicion was against only one food allergen related to latex, the tests were done with this specific food. All relevant and mandatory laboratory health and safety measures have been complied with in the complete course of the experiments.

\section{Precipitin's Titration}

A simplified serum dilution method for the semiquantitative tube titration of precipitins against soluble food allergens in a pure antigen-antibody system was performed. The patient's blood was collected in a clot-activator collecting tube. After serum separation, the tube was centrifugated at 2,000 rpm for 10 minutes. The allergen extracts were allocated in sets of nine glass tubes at progressive duplicated serum dilutions. The progressive dilutions were combined with the $15 \mu \mathrm{L}$ of the antigen $(1 \mathrm{mg} / \mathrm{mL}$ ) with $250 \mu \mathrm{L}$ of the patient's serum, progressively diluted into physiological saline solution $(\mathrm{NaCl} 0,9 \%)$ in the dilution ratios of $1: 1 ; 1: 2 ; 1: 4 ; 1: 8 ; 1: 16 ; 1: 32 ; 1: 64$ and $1: 128$. The ninth tube was a blank control done just with the serum to observe occasional spontaneous precipitation (cryoglobulins). After 24 hours, the tubes were examined by one of us and the titers (the highest dilution factor that yields a positive reading) were recorded [42].

\section{Tabular and Graphic Presentation of Data}

A total-data distribution table was constructed to allow an overview of the contribution of each precipitation test inside the context of each patient's perception (Appendix 1). A contingency table was elaborated according to the patient's perception of the effect of the Precipitin-based Elimination Diet (PED), evaluated by the Improvement Verbal Scale Rate (IVSR), and associated with the possibilities of combination between the positive/negative results of the precipitins' research and the patient's positive/negative perception after the reintroduction of each Symptom-Related Food Allergen (SRFA). The lowest precipitin titer, associated with each IVSR category row, was indicated in the positive precipitin/positive SRFA column. The highest precipitin titer, associated with each IVSR category row, was indicated in the positive precipitin/negative SRFA column (Table I). Another contingency table was elaborated distributing the precipitin's titration and the frequencies (\%) of patient's positive or negative SRFA (Table II). Based on this table, the correlation coefficient between the precipitin's titers and the percentages of positive reports was performed using GraphPad Prism software (version 5.0; GraphPad Software, Inc., San Diego, CA, USA). Also based on Table III, a graphic distribution of the frequency of the positive Symptom-Related Food Allergen (SRFA) was plotted according to each precipitin's titer (Fig. 1).

\section{RESULTS}

There was no spontaneous precipitation (cryoglobulins) on the control samples. There was also no suspended flocculation, all the positive reactions were observed as bottom precipitates. All recorded data of the patients: age, sex, suspected food allergens, IVSR, titers of the precipitation titrations, and positive or negative SRFA are presented in Appendix 1. The proportion of positive precipitins for each tested allergen were (positive tests/total tested): Brazil nut $(1 / 1)$, banana $(1 / 3)$, bovine meat $(2 / 3)$ chicken meat $(1 / 4)$, cocoa (7/44), cow's milk (24/37), egg's white (5/13), egg's yolk $(2 / 2)$, tilapia $(0 / 2)$, garlic $(1 / 1)$, gluten $(8 / 22)$, latexrelated food (or Hevea brasiliensis latex for skin and blood tests) $(19 / 56)$, nut $(1 / 1)$, onion $(1 / 1)$, orange $(3 / 5)$, peanut $(28 / 45)$, pecan nut $(1 / 1)$, red bean $(0 / 1)$, red pepper $(0 / 1)$, rice $(0 / 1)$, shrimp (1/1), soybean (3/4), swine meat (34/42), tomato $(0 / 10)$, bread/beer Saccharomyces cerevisiae yeast $(6 / 21)$. Table II shows that $42(65,6 \%)$ of the 64 patients presented at least a $70 \%$ improvement of the symptoms after the PED, allowing a clear field to facilitate the perception of a positive/negative SRFA. Table I also shows that the highest titer associated with a negative SRFA is $1: 32$; meaning that greater titers will be more probably associated with a positive SRFA. Table 1 also shows that even low titers such as 1:2 may be associated with positive SRFA. Therefore, the titer's range interval from 1:2 to $1: 32$ is not predictive of a positive or negative SRFA. Table II shows to each precipitin's titer, the probabilities of a positive or negative SRFA. From this data, if one considers the positive SRFA as a true indicator of hypersensitivity, we may infer that when the precipitin's titer is $1: 64$ or $1: 128$ the sensibility of the test is $100 \%$ (all tests with these titers were associated with a positive SRFA). 
Likewise, if one considers the negative SRFA as a true indicator of the inexistence of hypersensitivity, we may infer that the specificity of the test is $100 \%$ (no negative precipitin was associated with a positive SRFA). The correlation coefficient calculated between the titers of the food-specific precipitins and the corresponding percentages of positive SRFA showed a significant correlation (alpha $=0.05$ ) Pearson $\mathrm{r}=0.91 ; 95 \%$ confidence interval $(0.61$ to 0.98$) ; \mathrm{p}$-value $=$ $0.0004 ; \mathrm{R}$ square $=0.82$.

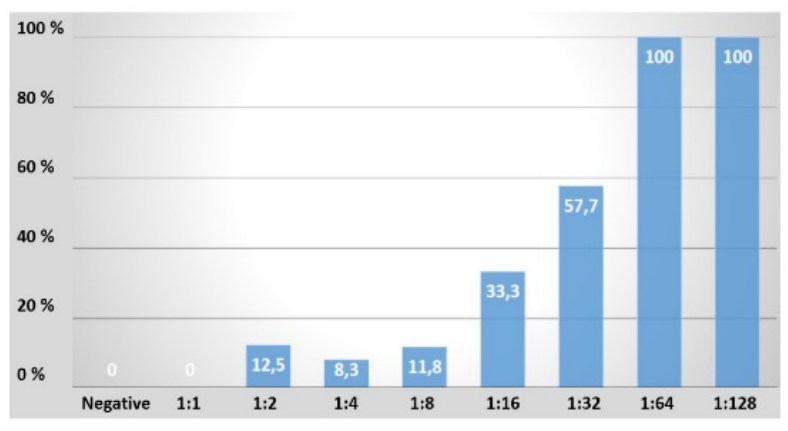

Fig. 1. Graphic distribution of the frequency (\%) of the positive SymptomRelated Food Allergen (SRFA) according to each precipitin's titer.

TABLE I: CONTINGENCY TABLE Distributed ACCORDING TO THE TENFOLD GRADUATED PATIENT'S PERCEPTION OF THE EFFECT OF THE PRECIPITINBASED ELIMINATION DIET (PED), EVALUATED BY THE IMPROVEMENT VERBAL SCALE RATE (IVSR), ASSOCIATED WITH THE FOUR POSSIBILITIES OF

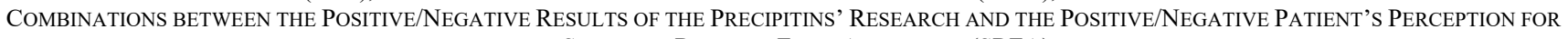

\begin{tabular}{|c|c|c|c|c|c|}
\hline $\begin{array}{c}\text { IVRS }(\%) \\
\text { (Number of patients) }\end{array}$ & $\begin{array}{l}\text { Number of } \\
\text { Tests }\end{array}$ & $\begin{array}{c}\text { Positive Precipitin } \\
\text { Positive SRFA } \\
\text { (Lowest titer) } \\
\end{array}$ & $\begin{array}{c}\text { Positive Precipitin } \\
\text { Negative SRFA } \\
\text { (Highest titer) } \\
\end{array}$ & $\begin{array}{c}\text { Negative } \\
\text { Precipitin } \\
\text { Positive SRFA } \\
\end{array}$ & $\begin{array}{l}\text { Negative Precipitin } \\
\text { Negative SRFA }\end{array}$ \\
\hline $10 \%(3)$ & 12 & $101(1: 8)$ & $5(1: 8)$ & 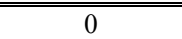 & $\bar{~} 6$ \\
\hline $20 \%(2)$ & 9 & $2(1: 8)$ & $4(1: 16)$ & 0 & 3 \\
\hline $30 \%(5)$ & 26 & $4(1: 4)$ & $17(1: 32)$ & 0 & 5 \\
\hline $40 \%$ (3) & 15 & $7(1: 16)$ & $7(1: 16)$ & 0 & 1 \\
\hline $50 \%(3)$ & 16 & $4(1: 16)$ & $10(1: 16)$ & 0 & 2 \\
\hline $60 \%(6)$ & 26 & $13(1: 16)$ & $12(1: 32)$ & 0 & 1 \\
\hline $70 \%(14)$ & 67 & $31(1: 8)$ & $32(1: 32)$ & 0 & 4 \\
\hline $80 \%(16)$ & 78 & $46(1: 2)$ & $21(1: 32)$ & 0 & 11 \\
\hline $90 \%(7)$ & 39 & $26(1: 4)$ & $6(1: 16)$ & 0 & 7 \\
\hline $100 \%(5)$ & 24 & $15(1: 64)$ & $7(1: 32)$ & 0 & 2 \\
\hline Total (64) & 312 & 149 & 121 & 0 & 42 \\
\hline
\end{tabular}

The lowest precipitin titer associated with each IVSR Category Row is Indicated in the positive precipitin/positive SRFA column. The highest precipitin titer associated with each IVSR category row is indicated in the positive precipitin/negative SRFA column.

TABLE II: CONTINGENCY TABLE DISTRIBUTION OF PRECIPITIN'S TITERS RELATED WITH THE NUMBER OF REPORTS OF POSITIVE AND NEGATIVE SYMPTOM-RELATED FOOD ALLERGENS (SRFA)

\begin{tabular}{|c|c|c|c|}
\hline $\begin{array}{l}\text { Precipitin's } \\
\text { Titer } \\
\end{array}$ & $\begin{array}{l}\text { Number } \\
\text { of Tests }\end{array}$ & $\begin{array}{l}\text { Positive } \\
\text { SRFA }\end{array}$ & $\begin{array}{l}\text { Negative } \\
\text { SRFA }\end{array}$ \\
\hline Negative & 42 & $0(0,0 \%)$ & $42(100,0 \%)$ \\
\hline $1: 1$ & 3 & $0(0,0 \%)$ & $3(100,0 \%)$ \\
\hline $1: 2$ & 8 & $1(12,5 \%)$ & $7(87,5 \%)$ \\
\hline $1: 4$ & 36 & $3(8,3 \%)$ & $33(91,7 \%)$ \\
\hline $1: 8$ & 51 & $6(11,8 \%)$ & $45(88,2 \%)$ \\
\hline $1: 16$ & 33 & $11(33,3 \%)$ & $22(66,7 \%)$ \\
\hline $1: 32$ & 26 & $15(57,7 \%)$ & $11(42,3 \%)$ \\
\hline $1: 64$ & 19 & $19(100,0 \%)$ & $0(0,0 \%)$ \\
\hline $1: 128$ & 94 & $94(100,0 \%)$ & $0(0,0 \%)$ \\
\hline TOTAL & 312 & $149(47,8 \%)$ & $163(52,2 \%)$ \\
\hline
\end{tabular}

\section{DISCUSSION}

One of the main physiologic defenses against food allergy is the gastrointestinal digestion of food proteins [43], [44]. Any disturbance of the digestion processes (even a simple antacid or an alteration on mucosal microbiota) may constitute a predisposition factor to the immune sensitization against food antigens [45]-[47]. The main purpose of the gastrointestinal barriers is to block the undesirable entrance of immunoreactive food proteins into the bloodstream [48]. When foreign proteins gain access to the internal milieu, specific antibodies are produced to inactivate these proteins, allowing their clearing from circulation by the reticuloendothelial system [49]. When the allergic patient develops an IgE-mediated food allergy, it is relatively easy to prove a causal relationship between the specific allergen(s) and the clinical symptoms. Now a day, the medical community has access to very comprehensive reviews, algorithms, and guidelines to manage IgE-mediated food allergies [50], [51]. However, when the patient develops a non-IgE mediated hypersensitivity, such as in the case of the $\mathrm{IAD}$, the demonstration of the causal agents is not an easy task. The contribution of food-specific IgG antibodies to the pathogenesis of food allergy is now a day a controversial field [52]-[54]. Before the association of IgE with immediate reactions, in 1967, the research of precipitins and soluble immune-complexes against food allergens were historically used to study allergy [55]-[58]. The association of the IgE to the reaginic reactions, somehow dodged the attention from the non-IgE mediated hypersensitivity [59]. Nevertheless, even after this insight, some colleagues were yet able to report and associate food-specific non-IgE mediated mechanisms to their patients' hypersensitivities [60], [61]. Our results, in similarity with these previous reports, also suggest that an excessive immune response produced against inappropriately blood-acquired undigested food allergens may participate in the production of IAD symptoms. The specific antibodies remarked by the precipitin's titration maybe not, necessarily, the etiologic agents responsible for the production of the IAD inflammation. They can simply be considered a marker of intestinal persorption of undigested food antigens and/or of occasional opportunistic microbial toxins that may add participation to the inflammatory reactions [62]-[64]. The assistant physician that read this paper must be assured that the research of food-specific precipitins is not here defined as a confirmatory assay able to diagnose, solely by itself, any kind of disease, intolerance, hypersensitivity, or allergy [65]. It just proposes the use of the precipitin's titration as a predictive screening pre-test to elaborate a justified 
Elimination Diet as a starting point to initiate the already established golden-standard procedure to diagnose food allergy: the OFC. Here we report a preliminary feasibility study performed in real life, evaluating the subjective perception of a small group of patients with different characteristics and that were treated according to their particular symptoms and comorbidities. There was no control group and the unblinded patients may have been suggested by the results of the exams, focusing their attention on the appointed food allergens that had already been conjointly selected by anamnesis. More multi-center studies are needed, with double-blind placebo-controlled strategies, evaluating more food allergens, as well with a greater range of serum dilutions to better appreciated the equivalence zone between the antigen-excess/antibody-excess areas. Anyway, the titration of food-specific precipitins, prescribed according to the patient's perceptions and dietary habits, helped to provide a clean field to initiate the clinical management; added confidence and adherence to the elimination diet; as well showed a good correlation with the clinical diagnosis [66]. The study's design does not allow a strong level of evidence to take definitive conclusions but opens an avenue of investigation in the direction of the titration of precipitins, as an easy and unexpensive strategy to clarify the non- $\operatorname{IgE}$ mediated hypersensitivities reactions that haunt the IAD patients.

\section{ABBREVIATIONS}

AD: Atopic Dermatitis

IAD: Intrinsic Atopic Dermatitis

PED: Precipitins-based Elimination Diet

IVSR: Improvement Verbal Scale Rate (related with the PED)

SRFA: Symptom-Related Food Allergen (positive or negative) OFC: Oral Food Challenge test

\section{APPENDIX}

Total data distribution table of 312 allergen-specific precipitation titers done with 64 IAD patients according to their improvement Verbal Scale Rate (IVSR) perception of the benefits of a Precipitin-based Elimination Diet (PED) and their positive or negative perception of the impairment of the symptoms after the reintroduction of each excluded Symptom-Related Food Allergen (SRFA)

\begin{tabular}{|c|c|c|c|c|c|c|c|c|c|c|c|c|c|}
\hline Patient & Sex & Age & $\begin{array}{c}\text { IVRS } \\
(\%) \\
\end{array}$ & Food Allergen & $\begin{array}{c}\text { Precipitin } \\
\text { Titer }\end{array}$ & SRFA & Patient & Sex & Age & $\begin{array}{c}\text { IVRS } \\
(\%) \\
\end{array}$ & $\begin{array}{c}\text { Food } \\
\text { Allergen }\end{array}$ & $\begin{array}{c}\text { Precipitin } \\
\text { Titer }\end{array}$ & SRFA \\
\hline$\overline{\mathrm{AA}}$ & $\bar{M}$ & 36 & 10 & Egg's white & Negative & Negative & $\overline{\mathrm{AS}}$ & $\overline{\mathrm{M}}$ & 39 & 70 & Cow's milk & $1: 8$ & Positive \\
\hline AA & M & 36 & 10 & Gluten & Negative & Negative & AS & $\mathrm{M}$ & 39 & 70 & Egg's white & $1: 128$ & Positive \\
\hline AA & M & 36 & 10 & Latex & Negative & Negative & AS & M & 39 & 70 & Egg's yolk & $1: 128$ & Positive \\
\hline $\mathrm{AB}$ & $\mathrm{F}$ & 53 & 80 & Cocoa & $1: 16$ & Negative & AS & $\mathrm{M}$ & 39 & 70 & Yeast & $1: 8$ & Positive \\
\hline $\mathrm{AB}$ & $\mathrm{F}$ & 53 & 80 & Egg's white & $1: 16$ & Negative & AT & $\mathrm{M}$ & 90 & 90 & Cocoa & $1: 8$ & Negative \\
\hline $\mathrm{AB}$ & $\mathrm{F}$ & 53 & 80 & Latex & $1: 32$ & Positive & AT & $\mathrm{M}$ & 90 & 90 & Cow's milk & $1: 128$ & Positive \\
\hline $\mathrm{AB}$ & $\mathrm{F}$ & 53 & 80 & Peanut & $1: 128$ & Positive & AT & $\mathrm{M}$ & 90 & 90 & Gluten & $1: 128$ & Positive \\
\hline $\mathrm{AB}$ & $\mathrm{F}$ & 53 & 80 & Swine meat & $1: 128$ & Positive & AT & $\mathrm{M}$ & 90 & 90 & Latex & $1: 128$ & Positive \\
\hline $\mathrm{AC}$ & M & 26 & 70 & Cocoa & $1: 8$ & Negative & AT & $\mathrm{M}$ & 90 & 90 & Peanut & $1: 128$ & Positive \\
\hline $\mathrm{AC}$ & M & 26 & 70 & Latex & $1: 8$ & Negative & AT & $\mathrm{M}$ & 90 & 90 & Swine meat & $1: 128$ & Positive \\
\hline $\mathrm{AC}$ & M & 26 & 70 & Peanut & $1: 8$ & Negative & $\mathrm{AV}$ & $\mathrm{F}$ & 49 & 20 & Cocoa & $1: 8$ & Positive \\
\hline $\mathrm{AC}$ & M & 26 & 50 & Swine meat & $1: 128$ & Positive & $\mathrm{AV}$ & $\mathrm{F}$ & 49 & 20 & Cow's milk & $1: 4$ & Negative \\
\hline $\mathrm{AC}$ & M & 54 & 50 & Yeast & $1: 8$ & Negative & $\mathrm{AV}$ & $\mathrm{F}$ & 49 & 20 & Gluten & $1: 8$ & Negative \\
\hline $\mathrm{AD}$ & M & 54 & 50 & Cow's milk & $1: 16$ & Positive & $\mathrm{AV}$ & $\mathrm{F}$ & 49 & 20 & Latex & $1: 16$ & Negative \\
\hline $\mathrm{AD}$ & M & 54 & 50 & Egg's white & $1: 4$ & Negative & $\mathrm{AV}$ & $\mathrm{F}$ & 49 & 20 & Swine meat & Negative & Negative \\
\hline $\mathrm{AD}$ & M & 54 & 50 & Latex & Negative & Negative & $\mathrm{AZ}$ & $\mathrm{M}$ & 73 & 70 & Cocoa & $1: 4$ & Negative \\
\hline $\mathrm{AD}$ & M & 54 & 50 & Red pepper & $1: 1$ & Negative & $\mathrm{AZ}$ & $\mathrm{M}$ & 73 & 70 & Cow's milk & $1: 128$ & Positive \\
\hline $\mathrm{AD}$ & M & 54 & 50 & Yeast & $1: 4$ & Negative & $\mathrm{AZ}$ & $\mathrm{M}$ & 73 & 70 & Latex & $1: 16$ & Negative \\
\hline $\mathrm{AL}$ & $\mathrm{F}$ & 58 & 60 & Brazil nut & $1: 16$ & Positive & $\mathrm{AZ}$ & $\mathrm{M}$ & 73 & 70 & Peanut & $1: 128$ & Negative \\
\hline $\mathrm{AL}$ & $\mathrm{F}$ & 58 & 60 & Latex & $1: 4$ & Negative & $\mathrm{AZ}$ & $\mathrm{M}$ & 73 & 70 & Swine meat & $1: 128$ & Positive \\
\hline $\mathrm{AL}$ & $\mathrm{F}$ & 58 & 60 & Nuts & $1: 16$ & Positive & BS & $\mathrm{F}$ & 31 & 70 & Cocoa & $1: 8$ & Negative \\
\hline $\mathrm{AL}$ & $\mathrm{F}$ & 58 & 60 & Peanut & $1: 4$ & Negative & BS & $\mathrm{F}$ & 31 & 70 & Cow's milk & $1: 128$ & Positive \\
\hline $\mathrm{AL}$ & $\mathrm{F}$ & 58 & 60 & Pecan nuts & $1: 16$ & Positive & BS & $\mathrm{F}$ & 31 & 70 & Latex & $1: 8$ & Negative \\
\hline $\mathrm{AM}$ & $\mathrm{F}$ & 87 & 90 & Bovine meat & $1: 64$ & Positive & BS & $\mathrm{F}$ & 31 & 70 & Peanut & $1: 128$ & Positive \\
\hline $\mathrm{AM}$ & $\mathrm{F}$ & 87 & 90 & Chicken meat & $1: 4$ & Negative & BS & $\mathrm{F}$ & 31 & 70 & Soybean & $1: 8$ & Negative \\
\hline $\mathrm{AM}$ & $\mathrm{F}$ & 87 & 90 & Cocoa & $1: 8$ & Negative & $\mathrm{CC}$ & $\mathrm{F}$ & 63 & 90 & Cocoa & $1: 128$ & Positive \\
\hline $\mathrm{AM}$ & $\mathrm{F}$ & 87 & 90 & Cow's milk & Negative & Negative & $\mathrm{CC}$ & $\mathrm{F}$ & 63 & 90 & Cow's milk & $1: 128$ & Positive \\
\hline $\mathrm{AM}$ & $\mathrm{F}$ & 87 & 90 & Egg's yolk & $1: 128$ & Positive & $\mathrm{CC}$ & $\mathrm{F}$ & 63 & 90 & Latex & $1: 128$ & Positive \\
\hline $\mathrm{AM}$ & $\mathrm{F}$ & 87 & 90 & Gluten & Negative & Negative & $\mathrm{CC}$ & $\mathrm{F}$ & 63 & 90 & Peanut & $1: 128$ & Positive \\
\hline AM & $\mathrm{F}$ & 87 & 90 & Latex & Negative & Negative & $\mathrm{CC}$ & $\mathrm{F}$ & 63 & 90 & Swine meat & $1: 128$ & Positive \\
\hline $\mathrm{AM}$ & $\mathrm{F}$ & 87 & 90 & Swine meat & $1: 128$ & Positive & $\mathrm{CF}$ & $\mathrm{F}$ & 63 & 80 & Cow's milk & $1: 64$ & Positive \\
\hline AN & $\mathrm{F}$ & 84 & 70 & Cocoa & $1: 4$ & Negative & $\mathrm{CF}$ & $\mathrm{F}$ & 63 & 80 & Egg's white & $1: 64$ & Positive \\
\hline $\mathrm{AN}$ & $\mathrm{F}$ & 84 & 70 & Latex & $1: 2$ & Negative & $\mathrm{CF}$ & $\mathrm{F}$ & 63 & 80 & Gluten & $1: 32$ & Negative \\
\hline $\mathrm{AN}$ & $\mathrm{F}$ & 84 & 70 & Peanut & $1: 16$ & Positive & $\mathrm{CF}$ & $\mathrm{F}$ & 63 & 80 & Latex & $1: 128$ & Positive \\
\hline $\mathrm{AN}$ & $\mathrm{F}$ & 84 & 70 & Swine meat & $1: 128$ & Positive & $\mathrm{CF}$ & $\mathrm{F}$ & 63 & 80 & Swine meat & $1: 8$ & Negative \\
\hline $\mathrm{AN}$ & $\mathrm{F}$ & 84 & 70 & Yeast & $1: 64$ & Positive & DD & $\mathrm{M}$ & 61 & 60 & Cocoa & $1: 16$ & Negative \\
\hline $\mathrm{AP}$ & $\mathrm{F}$ & 51 & 10 & Cocoa & $1: 4$ & Negative & DD & $\mathrm{M}$ & 61 & 60 & Cow's milk & $1: 32$ & Negative \\
\hline AP & $\mathrm{F}$ & 51 & 10 & Gluten & Negative & Negative & $\mathrm{DD}$ & $\mathrm{M}$ & 61 & 60 & Latex & $1: 8$ & Negative \\
\hline $\mathrm{AP}$ & $\mathrm{F}$ & 51 & 10 & Latex & $1: 4$ & Negative & DD & M & 61 & 60 & Peanut & $1: 32$ & Positive \\
\hline AP & $\mathrm{F}$ & 51 & 10 & Peanut & Negative & Negative & DD & $\mathrm{M}$ & 61 & 60 & Swine meat & $1: 32$ & Positive \\
\hline AP & $\mathrm{F}$ & 51 & 10 & Swine meat & $1: 2$ & Negative & DL & $\mathrm{F}$ & 73 & 80 & Cocoa & $1: 4$ & Positive \\
\hline $\mathrm{AR}$ & $\mathrm{F}$ & 23 & 80 & Bovine meat & $1: 16$ & Positive & $\mathrm{DL}$ & $\mathrm{F}$ & 73 & 80 & Cow's milk & $1: 128$ & Positive \\
\hline $\mathrm{AR}$ & $\mathrm{F}$ & 23 & 80 & Garlic & $1: 128$ & Positive & DL & $\mathrm{F}$ & 73 & 80 & Gluten & $1: 64$ & Negative \\
\hline $\mathrm{AR}$ & $\mathrm{F}$ & 23 & 80 & Garlic & $1: 128$ & Positive & DL & $\mathrm{F}$ & 73 & 80 & Latex & $1: 8$ & Positive \\
\hline $\mathrm{AR}$ & $\mathrm{F}$ & 23 & 80 & Onion & $1: 8$ & Positive & DL & $\mathrm{F}$ & 73 & 80 & Peanut & $1: 16$ & Positive \\
\hline AR & $\mathrm{F}$ & 23 & 80 & Red bean & $1: 8$ & Negative & $\mathrm{CF}$ & $\mathrm{F}$ & 63 & 80 & Cow's milk & $1: 64$ & \\
\hline AS & M & 39 & 70 & Banana & $1: 8$ & Negative & $\mathrm{CF}$ & $\mathrm{F}$ & 63 & 80 & Egg's white & $1: 64$ & \\
\hline
\end{tabular}




\begin{tabular}{|c|c|c|c|c|c|c|c|c|c|c|c|c|c|}
\hline Patient & Sex & Age & $\begin{array}{c}\text { IVRS } \\
(\%) \\
\end{array}$ & Food Allergen & $\begin{array}{c}\text { Precipitin } \\
\text { Titer } \\
\end{array}$ & SRFA & Patient & Sex & Age & $\begin{array}{c}\text { IVRS } \\
(\%) \\
\end{array}$ & Food Allergen & $\begin{array}{c}\text { Precipitin } \\
\text { Titer } \\
\end{array}$ & SRFA \\
\hline $\mathrm{CF}$ & $\mathrm{F}$ & 63 & 80 & Gluten & $1: 32$ & Negative & GR & $\mathrm{M}$ & 64 & 70 & Egg's white & $1: 128$ & Positive \\
\hline $\mathrm{CF}$ & $\mathrm{F}$ & 63 & 80 & Latex & $1: 128$ & Positive & GR & M & 64 & 70 & Latex & $1: 32$ & Negative \\
\hline $\mathrm{CF}$ & $\mathrm{F}$ & 63 & 80 & Swine meat & $1: 8$ & Negative & GR & M & 64 & 70 & Peanut & $1: 32$ & Positive \\
\hline DD & M & 61 & 60 & Cocoa & $1: 16$ & Negative & GR & M & 64 & 30 & Swine meat & $1: 128$ & Positive \\
\hline DD & M & 61 & 60 & Cow's milk & $1: 32$ & Negative & IL & $\mathrm{F}$ & 38 & 30 & Cow's milk & Negative & Negative \\
\hline DD & M & 61 & 60 & Latex & $1: 8$ & Negative & IL & $\mathrm{F}$ & 38 & 30 & Gluten & Negative & Negative \\
\hline DD & M & 61 & 60 & Peanut & $1: 32$ & Positive & IL & $\mathrm{F}$ & 38 & 30 & Peanut & Negative & Negative \\
\hline $\mathrm{DD}$ & M & 61 & 60 & Swine meat & $1: 32$ & Positive & IL & $\mathrm{F}$ & 38 & 30 & Swine meat & $1: 32$ & Positive \\
\hline $\mathrm{DL}$ & $\mathrm{F}$ & 73 & 80 & Cocoa & $1: 4$ & Negative & IL & $\mathrm{F}$ & 38 & 30 & Yeast & $1: 4$ & Negative \\
\hline $\mathrm{DL}$ & $\mathrm{F}$ & 73 & 80 & Cow's milk & $1: 128$ & Positive & IM & $\mathrm{F}$ & 31 & 70 & Cocoa & $1: 1$ & Negative \\
\hline $\mathrm{DL}$ & $\mathrm{F}$ & 73 & 80 & Gluten & $1: 64$ & Positive & IM & $\mathrm{F}$ & 31 & 70 & Latex & $1: 2$ & Negative \\
\hline $\mathrm{DL}$ & $\mathrm{F}$ & 73 & 80 & Latex & $1: 8$ & Positive & IM & $\mathrm{F}$ & 31 & 70 & Peanut & $1: 64$ & Positive \\
\hline DL & $\mathrm{F}$ & 73 & 80 & Peanut & $1: 16$ & Negative & IM & $\mathrm{F}$ & 31 & 70 & Swine meat & $1: 128$ & Positive \\
\hline EA & $\mathrm{F}$ & 56 & 60 & Chicken meat & $1: 16$ & Negative & IM & $\mathrm{F}$ & 31 & 70 & Yeast & Negative & Negative \\
\hline EA & $\mathrm{F}$ & 56 & 60 & Cocoa & $1: 8$ & Negative & $\mathrm{JF}$ & M & 70 & 60 & Cow's milk & $1: 32$ & Positive \\
\hline EA & $\mathrm{F}$ & 56 & 60 & Cow's milk & $1: 128$ & Positive & $\mathrm{JF}$ & M & 70 & 60 & Gluten & $1: 64$ & Positive \\
\hline EA & $\mathrm{F}$ & 56 & 60 & Eggs's white & $1: 16$ & Negative & $\mathrm{JF}$ & M & 70 & 60 & Latex & $1: 2$ & Negative \\
\hline EA & $\mathrm{F}$ & 56 & 60 & Swine meat & $1: 32$ & Positive & $\mathrm{JM}$ & $\mathrm{F}$ & 24 & 30 & Chicken meat & $1: 32$ & Positive \\
\hline $\mathrm{EF}$ & $\mathrm{F}$ & 42 & 10 & Cow's milk & $1: 8$ & Negative & $\mathrm{JM}$ & $\mathrm{F}$ & 24 & 30 & Fish (Tilapia) & $1: 2$ & Negative \\
\hline $\mathrm{EF}$ & $\mathrm{F}$ & 42 & 10 & Egg's white & $1: 4$ & Negative & $\mathrm{JM}$ & $\mathrm{F}$ & 24 & 30 & Gluten & Negative & Negative \\
\hline $\mathrm{EF}$ & $\mathrm{F}$ & 42 & 10 & Latex & $1: 8$ & Positive & $\mathrm{JM}$ & $\mathrm{F}$ & 24 & 30 & Latex & $1: 8$ & Negative \\
\hline $\mathrm{EF}$ & $\mathrm{F}$ & 42 & 10 & Orange & Negative & Negative & $\mathrm{JM}$ & $\mathrm{F}$ & 24 & 30 & Rice & $1: 4$ & Negative \\
\hline EG & $\mathrm{F}$ & 80 & 70 & Latex & $1: 4$ & Negative & $\mathrm{JM}$ & $\mathrm{F}$ & 24 & 30 & Soybean & $1: 4$ & Positive \\
\hline EG & $\mathrm{F}$ & 80 & 70 & Peanut & $1: 64$ & Positive & $\mathrm{JO}$ & $\mathrm{F}$ & 32 & 80 & Cocoa & $1: 128$ & Positive \\
\hline EG & $\mathrm{F}$ & 80 & 70 & Swine meat & $1: 128$ & Positive & $\mathrm{JO}$ & $\mathrm{F}$ & 32 & 80 & Orange & $1: 8$ & Negative \\
\hline EM & $\mathrm{F}$ & 56 & 80 & Cocoa & Negative & Negative & $\mathrm{JO}$ & $\mathrm{F}$ & 32 & 80 & Peanut & $1: 64$ & Positive \\
\hline EM & $\mathrm{F}$ & 56 & 80 & Cow's milk & Negative & Negative & $\mathrm{JO}$ & $\mathrm{F}$ & 32 & 80 & Soybean & $1: 32$ & Positive \\
\hline EM & $\mathrm{F}$ & 56 & 80 & Egg's white & Negative & Negative & $\mathrm{JO}$ & $\mathrm{F}$ & 32 & 80 & Swine meat & $1: 32$ & Positive \\
\hline EM & $\mathrm{F}$ & 56 & 80 & Latex & $1: 128$ & Positive & JP & M & 60 & 40 & Bovine meat & $1: 1$ & Negative \\
\hline EM & $\mathrm{F}$ & 56 & 80 & Orange & $1: 128$ & Positive & $\mathrm{JP}$ & M & 60 & 40 & Cocoa & $1: 8$ & Negative \\
\hline $\mathrm{EO}$ & $\mathrm{F}$ & 78 & 90 & Cocoa & $1: 128$ & Positive & JP & M & 60 & 40 & Cow's milk & $1: 16$ & Negative \\
\hline $\mathrm{EO}$ & $\mathrm{F}$ & 78 & 90 & Cow's milk & $1: 4$ & Negative & JP & M & 60 & 40 & Peanut & $1: 128$ & Positive \\
\hline $\mathrm{EO}$ & $\mathrm{F}$ & 78 & 90 & Gluten & $1: 4$ & Negative & JP & M & 60 & 40 & Swine meat & $1: 32$ & Positive \\
\hline $\mathrm{EO}$ & $\mathrm{F}$ & 78 & 90 & Latex & $1: 4$ & Positive & JR & $\mathrm{F}$ & 31 & 90 & Cocoa & $1: 16$ & Negative \\
\hline $\mathrm{EO}$ & $\mathrm{F}$ & 78 & 90 & Peanut & $1: 128$ & Positive & JR & $\mathrm{F}$ & 31 & 90 & Latex & $1: 128$ & Positive \\
\hline $\mathrm{EO}$ & $\mathrm{F}$ & 78 & 90 & Swine meat & $1: 128$ & Positive & JR & $\mathrm{F}$ & 31 & 90 & Peanut & $1: 128$ & Positive \\
\hline ER & $\mathrm{F}$ & 39 & 80 & Cocoa & Negative & Negative & $\mathrm{KC}$ & M & 24 & 80 & Swine meat & $1: 128$ & Positive \\
\hline ER & $\mathrm{F}$ & 39 & 80 & Latex & $1: 128$ & Positive & $\mathrm{KC}$ & M & 24 & 80 & Cow's milk & $1: 128$ & Positive \\
\hline ER & $\mathrm{F}$ & 39 & 80 & Peanut & Negative & Negative & $\mathrm{KC}$ & M & 24 & 80 & Egg's white & $1: 4$ & Positive \\
\hline ER & $\mathrm{F}$ & 39 & 80 & Swine meat & $1: 128$ & Positive & $\mathrm{KC}$ & M & 24 & 80 & Latex & $1: 16$ & Negative \\
\hline ER & $\mathrm{F}$ & 39 & 80 & Yeast & $1: 8$ & Negative & $\mathrm{KC}$ & M & 24 & 80 & Peanut & $1: 128$ & Positive \\
\hline ES & $\mathrm{F}$ & 25 & 80 & Cow's milk & $1: 64$ & Positive & $\mathrm{KR}$ & $\mathrm{F}$ & 42 & 90 & Yeast & $1: 2$ & Negative \\
\hline ES & $\mathrm{F}$ & 25 & 80 & Latex & $1: 16$ & Positive & $\mathrm{KR}$ & $\mathrm{F}$ & 42 & 90 & Cocoa & Negative & Negative \\
\hline ES & $\mathrm{F}$ & 25 & 80 & Peanut & $1: 128$ & Positive & $\mathrm{KR}$ & $\mathrm{F}$ & 42 & 90 & Cow's milk & $1: 128$ & Positive \\
\hline ES & $\mathrm{F}$ & 25 & 80 & Swine meat & $1: 128$ & Positive & $\mathrm{KR}$ & $\mathrm{F}$ & 42 & 90 & Latex & $1: 128$ & Positive \\
\hline ES & $\mathrm{F}$ & 25 & 80 & Yeast & $1: 2$ & Negative & KR & $\mathrm{F}$ & 42 & 90 & Peanut & $1: 128$ & Positive \\
\hline GR & M & 64 & 70 & Cocoa & $1: 8$ & Negative & $\mathrm{KR}$ & $\mathrm{F}$ & 42 & 90 & Swine meat & $1: 128$ & Positive \\
\hline GR & $\mathrm{M}$ & 64 & 70 & Cow's milk & $1: 128$ & Positive & LB & $\mathrm{F}$ & 69 & 80 & Cocoa & Negative & Negative \\
\hline
\end{tabular}

\begin{tabular}{|c|c|c|c|c|c|c|c|c|c|c|c|c|c|}
\hline Patient & Sex & Age & $\begin{array}{c}\text { IVRS } \\
(\%) \\
\end{array}$ & $\begin{array}{c}\text { Food } \\
\text { Allergen } \\
\end{array}$ & $\begin{array}{c}\text { Precipitin } \\
\text { Titer } \\
\end{array}$ & SRFA & Patient & Sex & Age & $\begin{array}{c}\text { IVRS } \\
(\%) \\
\end{array}$ & Food Allergen & $\begin{array}{c}\text { Precipitin } \\
\text { Titer } \\
\end{array}$ & SRFA \\
\hline$\overline{\mathrm{LB}}$ & $\bar{F}$ & 69 & 80 & Latex & $1: 128$ & Positive & $\mathrm{MC}$ & $\bar{F}$ & 54 & 50 & Peanut & $1: 8$ & Negative \\
\hline LB & $\mathrm{F}$ & 69 & 80 & Peanut & $1: 16$ & Positive & $\mathrm{MC}$ & $\mathrm{F}$ & 54 & 50 & Swine meat & $1: 32$ & Positive \\
\hline $\mathrm{LJ}$ & M & 36 & 30 & Cocoa & $1: 16$ & Negative & MG & $\mathrm{F}$ & 79 & 40 & Cocoa & $1: 64$ & Positive \\
\hline $\mathrm{LJ}$ & M & 36 & 30 & Gluten & $1: 32$ & Negative & MG & F & 79 & 40 & Cow's milk & $1: 8$ & Negative \\
\hline $\mathrm{LJ}$ & M & 36 & 30 & Latex & $1: 8$ & Negative & MG & $\mathrm{F}$ & 79 & 40 & Gluten & $1: 16$ & Positive \\
\hline $\mathrm{LJ}$ & M & 36 & 30 & Peanut & $1: 16$ & Negative & MG & F & 79 & 40 & Latex & $1: 16$ & Negative \\
\hline LP & $\mathrm{F}$ & 35 & 20 & Cocoa & Negative & Negative & MH & $\mathrm{F}$ & 77 & 80 & Cocoa & $1: 8$ & Negative \\
\hline LP & F & 35 & 20 & Latex & $1: 4$ & Negative & $\mathrm{MH}$ & F & 77 & 80 & Orange & $1: 2$ & Positive \\
\hline LP & F & 35 & 20 & Peanut & Negative & Negative & MH & F & 77 & 80 & Peanut & Negative & Negative \\
\hline LP & $\mathrm{F}$ & 35 & 20 & Swine meat & $1: 32$ & Positive & $\mathrm{MH}$ & F & 77 & 80 & Swine meat & $1: 128$ & Positive \\
\hline $\mathrm{LT}$ & F & 23 & 30 & Cocoa & $1: 4$ & Negative & $\mathrm{MH}$ & F & 77 & 80 & Yeast & $1: 32$ & Negative \\
\hline $\mathrm{LT}$ & $\mathrm{F}$ & 23 & 30 & Latex & $1: 8$ & Negative & ML & F & 73 & 60 & Cow's milk & $1: 4$ & Negative \\
\hline $\mathrm{LT}$ & $\mathrm{F}$ & 23 & 30 & Peanut & $1: 128$ & Positive & ML & $\mathrm{F}$ & 73 & 60 & Egg's white & $1: 64$ & Positive \\
\hline $\mathrm{LT}$ & $\mathrm{F}$ & 23 & 30 & Swine meat & $1: 32$ & Negative & ML & F & 73 & 60 & Gluten & $1: 8$ & Negative \\
\hline MA & $\mathrm{F}$ & 49 & 70 & Cocoa & $1: 32$ & Negative & ML & F & 73 & 60 & Swine meat & $1: 16$ & Positive \\
\hline $\mathrm{MZ}$ & F & 58 & 100 & Latex & Negative & Negative & MM & F & 55 & 90 & Egg's white & Negative & Negative \\
\hline $\mathrm{MZ}$ & $\mathrm{F}$ & 58 & 100 & Peanut & $1: 128$ & Positive & MM & $\mathrm{F}$ & 55 & 90 & Latex & Negative & Negative \\
\hline $\mathrm{MZ}$ & $\mathrm{F}$ & 58 & 100 & Soybean & $1: 128$ & Positive & MM & F & 55 & 90 & Peanut & Negative & Negative \\
\hline $\mathrm{MZ}$ & $\mathrm{F}$ & 58 & 100 & Yeast & Negative & Negative & MM & F & 55 & 90 & Swine meat & $1: 128$ & Positive \\
\hline NJ & M & 50 & 80 & Cocoa & $1: 128$ & Positive & MM & $\mathrm{F}$ & 55 & 90 & Yeast & $1: 128$ & Positive \\
\hline NJ & M & 50 & 80 & Latex & $1: 128$ & Positive & MP & F & 53 & 70 & Chicken meat & $1: 8$ & Negative \\
\hline NJ & M & 50 & 80 & Peanut & $1: 8$ & Negative & MP & $\mathrm{F}$ & 53 & 70 & Cow's milk & $1: 128$ & Positive \\
\hline $\mathrm{NJ}$ & M & 50 & 80 & Swine meat & $1: 8$ & Negative & MP & $\mathrm{F}$ & 53 & 70 & Latex & $1: 16$ & Negative \\
\hline
\end{tabular}




\begin{tabular}{|c|c|c|c|c|c|c|c|c|c|c|c|c|c|}
\hline NM & $\mathrm{F}$ & 64 & 70 & Cocoa & $1: 16$ & Negative & MP & $\mathrm{F}$ & 53 & 70 & Tomato & $1: 4$ & Negative \\
\hline NM & $\mathrm{F}$ & 64 & 70 & Cow's milk & $1: 128$ & Positive & MR & $\mathrm{F}$ & 56 & 100 & Cocoa & $1: 32$ & Negative \\
\hline NM & $\mathrm{F}$ & 64 & 70 & Latex & $1: 4$ & Negative & MR & $\mathrm{F}$ & 56 & 100 & Latex & $1: 4$ & Negative \\
\hline NM & $\mathrm{F}$ & 64 & 70 & Peanut & $1: 128$ & Positive & MR & $\mathrm{F}$ & 5 & 100 & Peanut & $1: 32$ & Negative \\
\hline NR & $\mathrm{F}$ & 57 & 50 & Cocoa & $1: 16$ & Negative & MR & $\mathrm{F}$ & 56 & 100 & Swine meat & $1: 128$ & Positive \\
\hline NR & $\mathrm{F}$ & 57 & 50 & Cow's milk & $1: 8$ & Negative & MR & $\mathrm{F}$ & 56 & 100 & Yeast & $1: 4$ & Negative \\
\hline NR & $\mathrm{F}$ & 57 & 50 & Latex & Negative & Negative & MT & $\mathrm{F}$ & 36 & 80 & Cocoa & $1: 32$ & Negative \\
\hline NR & $\mathrm{F}$ & 57 & 50 & Swine meat & $1: 4$ & Negative & MT & $\mathrm{F}$ & 36 & 80 & Gluten & Negative & Negative \\
\hline NR & $\mathrm{F}$ & 57 & 50 & Yeast & $1: 128$ & Positive & MT & $\mathrm{F}$ & 36 & 80 & Latex & $1: 8$ & Negative \\
\hline $\mathrm{OA}$ & M & 79 & 80 & Banana & $1: 4$ & Negative & MT & $\mathrm{F}$ & 36 & 80 & Peanut & $1: 32$ & Positive \\
\hline $\mathrm{OA}$ & M & 79 & 80 & Cow's milk & $1: 128$ & Positive & MT & $\mathrm{F}$ & 36 & 80 & Swine meat & $1: 128$ & Positive \\
\hline $\mathrm{OA}$ & M & 79 & 80 & Orange & $1: 128$ & Positive & MV & $\mathrm{F}$ & 30 & 100 & Cocoa & $1: 16$ & Negative \\
\hline $\mathrm{OA}$ & M & 79 & 80 & Peanut & $1: 128$ & Positive & MV & $\mathrm{F}$ & 30 & 100 & Latex & $1: 16$ & Negative \\
\hline $\mathrm{OA}$ & M & 79 & 80 & Swine meat & $1: 128$ & Positive & MV & $\mathrm{F}$ & 30 & 100 & Peanut & $1: 128$ & Positive \\
\hline MA & $\mathrm{F}$ & 49 & 70 & Latex & $1: 64$ & Positive & MV & $\mathrm{F}$ & 30 & 100 & Yeast & $1: 128$ & Positive \\
\hline MA & $\mathrm{F}$ & 49 & 70 & Peanut & $1: 128$ & Positive & $\mathrm{MZ}$ & $\mathrm{F}$ & 58 & 100 & Cow's milk & $1: 128$ & Positive \\
\hline MA & $\mathrm{F}$ & 49 & 70 & Shrimp & $1: 64$ & Positive & $\mathrm{PR}$ & $\mathrm{F}$ & 20 & 100 & Cocoa & $1: 8$ & Negative \\
\hline MA & $\mathrm{F}$ & 49 & 70 & Yeast & $1: 128$ & Positive & PR & $\mathrm{M}$ & 20 & 100 & Cow's milk & $1: 128$ & Positive \\
\hline $\mathrm{MC}$ & $\mathrm{F}$ & 54 & 50 & Cocoa & $1: 4$ & Negative & PR & $\mathrm{M}$ & 20 & 100 & Gluten & $1: 128$ & Positive \\
\hline $\mathrm{MC}$ & $\mathrm{F}$ & 54 & 50 & Cow's milk & $1: 64$ & Positive & PR & M & 20 & 100 & Latex & $1: 128$ & Positive \\
\hline $\mathrm{MC}$ & $\mathrm{F}$ & 54 & 50 & Latex & $1: 16$ & Negative & PR & M & 20 & 100 & Peanut & $1: 128$ & Positive \\
\hline
\end{tabular}

\begin{tabular}{|c|c|c|c|c|c|c|c|c|c|c|c|c|c|}
\hline Patient & Sex & Age & $\begin{array}{c}\text { IVRS } \\
(\%)\end{array}$ & $\begin{array}{c}\text { Food } \\
\text { Allergen }\end{array}$ & $\begin{array}{c}\text { Precipitin } \\
\text { Titer }\end{array}$ & SRFA & Patient & Sex & Age & $\begin{array}{c}\text { IVRS } \\
(\%)\end{array}$ & $\begin{array}{c}\text { Food } \\
\text { Allergen }\end{array}$ & $\begin{array}{c}\text { Precipitin } \\
\text { Titer }\end{array}$ & SRFA \\
\hline PR & $\mathrm{M}$ & 20 & 100 & Swine meat & $1: 128$ & Positive & TM & $\bar{F}$ & 87 & 80 & Swine meat & $1: 128$ & Positive \\
\hline RL & $\mathrm{F}$ & 32 & 70 & Cocoa & $1: 18$ & Negative & $\mathrm{TP}$ & $\mathrm{F}$ & 62 & 40 & Cow's milk & Negative & Negative \\
\hline RL & $\mathrm{F}$ & 32 & 70 & Cow's milk & $1: 128$ & Positive & TP & $\mathrm{F}$ & 62 & 40 & Latex & $1: 4$ & Negative \\
\hline RL & $\mathrm{F}$ & 32 & 70 & Latex & $1: 4$ & Negative & $\mathrm{TP}$ & $\mathrm{F}$ & 62 & 40 & Peanut & $1: 128$ & Positive \\
\hline RL & $\mathrm{F}$ & 32 & 70 & Peanut & Negative & Negative & $\mathrm{TP}$ & $\mathrm{F}$ & 62 & 40 & Swine meat & $1: 64$ & Positive \\
\hline RL & $\mathrm{F}$ & 32 & 70 & Swine meat & $1: 8$ & Negative & TP & $\mathrm{F}$ & 62 & 40 & Yeast & $1: 8$ & Negative \\
\hline RM & $\mathrm{F}$ & 53 & 100 & Cocoa & $1: 64$ & Positive & WS & M & 57 & 80 & Banana & $1: 128$ & Positive \\
\hline $\mathrm{RM}$ & $\mathrm{F}$ & 53 & 100 & Cow's milk & $1: 128$ & Positive & WS & M & 57 & 80 & Cocoa & Negative & Negative \\
\hline RM & $\mathrm{F}$ & 53 & 100 & Gluten & $1: 128$ & Positive & WS & M & 57 & 80 & Cocoa & Negative & Negative \\
\hline $\mathrm{RM}$ & $\mathrm{F}$ & 53 & 100 & Latex & $1: 128$ & Positive & WS & M & 57 & 80 & Latex & Negative & Negative \\
\hline $\mathrm{SF}$ & $\mathrm{F}$ & 47 & 30 & Cocoa & $1: 4$ & Negative & WS & M & 57 & 80 & Peanut & $1: 8$ & Negative \\
\hline SF & $\mathrm{F}$ & 47 & 30 & Cow's milk & $1: 32$ & Negative & WV & M & 59 & 70 & Cow's milk & $1: 128$ & Positive \\
\hline SF & $\mathrm{F}$ & 47 & 30 & Gluten & $1: 8$ & Negative & WV & M & 59 & 70 & Gluten & Negative & Negative \\
\hline SF & $\mathrm{F}$ & 47 & 30 & Latex & Negative & Negative & WV & M & 59 & 70 & Latex & $1: 8$ & Negative \\
\hline $\mathrm{SF}$ & $\mathrm{F}$ & 47 & 30 & Peanut & $1: 4$ & Negative & WV & M & 59 & 70 & Peanut & $1: 8$ & Negative \\
\hline TA & $\mathrm{F}$ & 32 & 60 & Egg's white & Negative & Negative & WV & M & 59 & 70 & Yeast & $1: 8$ & Negative \\
\hline TA & $\mathrm{F}$ & 32 & 60 & Gluten & $1: 128$ & Positive & $\mathrm{ZP}$ & $\mathrm{F}$ & 85 & 70 & Cocoa & $1: 4$ & Negative \\
\hline TA & $\mathrm{F}$ & 32 & 60 & Latex & $1: 8$ & Negative & $\mathrm{ZP}$ & $\mathrm{F}$ & 85 & 70 & Gluten & Negative & Negative \\
\hline $\mathrm{TM}$ & $\mathrm{F}$ & 87 & 80 & Cocoa & $1: 16$ & Negative & $\mathrm{ZP}$ & $\mathrm{F}$ & 85 & 70 & Latex & $1: 8$ & Negative \\
\hline TM & $\mathrm{F}$ & 87 & 80 & Cow's milk & $1: 128$ & Positive & $\mathrm{ZP}$ & F & 85 & 70 & Swine meat & $1: 128$ & Positive \\
\hline TM & $\mathrm{F}$ & 87 & 80 & Latex & $1: 32$ & Positive & $\mathrm{ZP}$ & $\mathrm{F}$ & 85 & 70 & Yeast & $1: 8$ & Negative \\
\hline $\mathrm{TM}$ & $\mathrm{F}$ & 87 & 80 & Peanut & $1: 128$ & Positive & & & & & & & \\
\hline
\end{tabular}

\section{REFERENCES}

[1] Czarnowicki T, He H, Krueger JG, Guttman-Yassky E. Atopic dermatitis endotypes and implications for targeted therapeutics. Journal of Allergy and Clinical Immunology. 2018; 143: 1-11.

[2] Wick MR. Disorders characterized by predominant or exclusive dermal inflammation. Seminars in Diagnostic Pathology. 2017; 34: 273-84.

[3] Boothe WD, Tarbox JA, Tarbox MB. Atopic Dermatitis: Pathophysiology. Advances in Experimental Medicine and Biology. 2017; 2017: 21-37

[4] Pastar Z, Lipozencic J, Ljubojevic S. Etiopathogenesis of atopic dermatitis: an overview. Acta Dermatovenerol Croatica. 2005; 13: 54 62.

[5] Guttman-Yassky E, Lowes MA, Fuentes-Duculan J, Zaba LC, Cardinale I, Nograles KE, et al. Low Expression of the IL-23/Th17 Pathway in Atopic Dermatitis Compared to Psoriasis. The Journal of Immunology. 2008; 181: 7420-7.

[6] Bakker DS, Nierkens S, Knol EF, Giovannone B, Delemarre EM, van der Schaft J, et al. Confirmation of multiple endotypes in atopic dermatitis based on serum biomarkers. Journal of Allergy and Clinical Immunology. 2021; 147: 189-98.

[7] Czarnowicki T, He H, Krueger JG, Guttman-Yassky E. Atopic dermatitis endotypes and implications for targeted therapeutics. Journal of Allergy and Clinical Immunology. 2019; 143: 1-11.

[8] Torres T, Ferreira EO, Gonçalo M, Mendes-Bastos P, Selores M, Filipe P. Update on Atopic Dermatitis. Acta Médica Portuguesa. 2016; 32: 606.

[9] Matsumoto K, Morita H, Nakae S. New insights of human atopic dermatitis provided by mouse models: The Journal of Allergy and Clinical Immunology. 2021; 148(3): 722-724.
[10] Olivier CE, Pinto DG, Lima RPdS, Silva MDd, Santos RAPGd, Teixeira APM, et al. Assessment of Immunoreactivity against Therapeutic Options Employing the Leukocyte Adherence Inhibition Test as a Tool for Precision Medicine. European Journal of Clinical Medicine. 2021; 2: 40-5.

[11] Liu L, Chen J, Xu J, Yang Q, Gu C, Ni C, et al. Sublingual immunotherapy of atopic dermatitis in mite-sensitized patients: a multi-centre, randomized, double-blind, placebo-controlled study. Artificial Cells, Nanomedicine, and Biotechnology. 2019; 47: 35403547.

[12] Mastrandrea F. The potential role of allergen-specific sublingual immunotherapy in atopic dermatitis. American Journal of Clinical Dermatology. 2004; 5: 281-94.

[13] Olivier CE, Lima RPS, Argentão DGP, Silva MDd, Santos RAPG, Pensuti M, et al. Group-specific Multi-allergen Sublingual/Swallow Immunotherapy Improves the Quality of Life of Polysensitized Children and Adults with Allergic Rhinitis. Journal of Allergy \& Therapy. 2013; 4: 148

[14] Tokura Y. Extrinsic and intrinsic types of atopic dermatitis. Journal of Dermatological Science. 2016; 58: 1-7.

[15] Jiménez-Saiz R, Ellenbogen Y, Koenig JFE, Gordon ME, Walker TD, Rosace $\mathrm{D}$, et al. IgG1+ B-cell immunity predates $\operatorname{IgE}$ responses in epicutaneous sensitization to foods. Allergy. 2019; 74: 165-75.

[16] Roguedas-Contios A-M, Misery L. What is Intrinsic Atopic Dermatitis? Clinical Reviews in Allergy \& Immunology. 2011; 41:233.

[17] Rajka G. Prurigo Besnier (atopic dermatitis) with special reference to the role of allergic factors. II. The evaluation of the results of skin reactions. Acta Dermato-Venereologica. 1961; 41: 1-39.

[18] Hanifin JM, Rajka G. Diagnostic Features of Atopic Dermatitis. Acta Dermato-Venereologica. 1980; 60: 44-7.

[19] Yatagai T, Shimauchi T, Yamaguchi H, Sakabe J-i, Aoshima M, Ikeya $\mathrm{S}$, et al. Sensitive skin is highly frequent in extrinsic atopic dermatitis 
and correlates with disease severity markers but not necessarily with skin barrier impairment. Journal of Dermatological Science. 2018; 89: $33-9$.

[20] Gell PGH, Coombs RRA. Classification of Allergic Reactions Responsible for Clinical Hypersensitivity and Disease. Clinical Aspects of Immunology. $2^{\text {nd }}$ ed. Oxford: Blackwell Scientific Publications; 1968.

[21] Uzzaman A, Cho SH. Chapter 28: Classification of hypersensitivity reactions. Allergy and Asthma Proceedings. 2012; 33: 96-99.

[22] $\mathrm{Yu}$ W, Freeland DMH, Nadeau KC. Food allergy: immune mechanisms, diagnosis and immunotherapy. Nature Reviews Immunology. 2016; 16: 751-765.

[23] Yamaguchi H, Hirasawa N, Asakawa S, Okita K, Tokura Y. Intrinsic atopic dermatitis shows high serum nickel concentration. Allergology International. 2015; 64(3):282-4.

[24] Babbel J, Ramos C, Wangberg H, Luskin K, Simon R. Adverse reactions to food additives. Journal of Food Allergy. 2021; 3: 8-23.

[25] Lang DM, Oppenheimer JJ, Portnoy JM. Just listen to your patient. Journal of Allergy and Clinical Immunology. 2020; 146(6): 1343-1345.

[26] Olivier CE. Food Allergy. Journal of Allergy \& Therapy. 2013; S3: 004:1-7

[27] Upton JEM, Bird JA. Oral food challenges. Annals of Allergy, Asthma \& Immunology. 2020; 124: 451-458.

[28] Calvani M, Bianchi A, Reginelli C, Peresso M, Testa A. Oral Food Challenge. Medicina (Kaunas, Lithuania). 2019; 55: 651.

[29] Vlieg-Boerstra BJ, Bijleveld CM, van der Heide S, Beusekamp BJ, Wolt-Plompen SA, Kukler J, et al. Development and validation of challenge materials for double-blind, placebo-controlled food challenges in children. Journal of Allergy and Clinical Immunology. 2007; 113: 341-346.

[30] Settipane RA. Food allergy: Science of uncertainty and art of probability. Journal of Food Allergy. 2021; 3: 1-2.

[31] Lins MdGM, Horowitz MR, Silva GAPd, Motta MEFA. Oral food challenge test to confirm the diagnosis of cow's milk allergy. Jornal de Pediatria. 2010; 86: 285-289.

[32] Lozinsky AC, Meyer R, De Koker C, Dziubak R, Godwin H, Reeve K, et al. Time to symptom improvement using elimination diets in nonIgE-mediated gastrointestinal food allergies. Pediatric Allergy and Immunology. 2015; 26: 403-408.

[33] Molina-Infante J, Arias Á, Alcedo J, Garcia-Romero R, CasabonaFrances S, Prieto-Garcia A, et al. Step-up empiric elimination diet for pediatric and adult eosinophilic esophagitis: The 2-4-6 study. Journal of Allergy and Clinical Immunology. 2018; 141: 1365-1372.

[34] Xie Y, Zhou G, Xu Y, He B, Wang Y, Ma R, et al. Effects of Diet Based on IgG Elimination Combined with Probiotics on Migraine Plus Irritable Bowel Syndrome. Pain Research and Management. 2019; 2019: 7890461.

[35] Kulthanan K, Boochangkool K, Tuchinda P, Chularojanamontri L. Clinical features of the extrinsic and intrinsic types of adult-onset atopic dermatitis. Asia Pacific Allergy. 2011; 1: 80-6.

[36] Olivier CE, Argentão DGP, Santos RAPG, Silva MD, Lima RPS, Zollner RL. Skin scrape test: an inexpensive and painless skin test for recognition of immediate hypersensitivity in children and adults. The Open Allergy Journal. 2013; 6: 9-17.

[37] World Medical Association Declaration of Helsinki: ethical principles for medical research involving human subjects. JAMA. 2013; 310: 2191-2194.

[38] Reich A, Heisig M, Phan NQ, Taneda K, Takamori K, Takeuchi S, et al. Visual analogue scale: evaluation of the instrument for the assessment of pruritus. Acta Dermato-Venereologica. 2012; 92: $497-$ 501.

[39] Phan N, Blome C, Fritz F, Gerss J, Reich A, Ebata T, et al. Assessment of pruritus intensity: prospective study on validity and reliability of the visual analogue scale, numerical rating scale and verbal rating scale in 471 patients with chronic pruritus. Acta Dermato Venereologica. 2012; 92: 502-507.

[40] Coca AF. Studies in specific hypersensitiveness V. The preparation of fluid extracts and solutions for use in the diagnosis and treatment of the allergies with notes on the collection of pollens. The Journal of Immunology. 1922; 7: 163-78.

[41] Bradford MM. A rapid and sensitive method for the quantitation of microgram quantities of protein utilizing the principle of protein-dye binding. Analytical Biochemistry. 1976; 72: 248-54.

[42] Williams CA, Chase MW. Chapter 13 - Precipitation Reactions. Reactions of Antibodies with Soluble Antigens: Academic Press; 1971.

[43] Untersmayr E, Poulsen LK, Platzer MH, Pedersen MH, BoltzNitulescu G, Skov PS, et al. The effects of gastric digestion on codfish allergenicity. Journal of Allergy and Clinical Immunology. 2005; 115: 377-382.
[44] Untersmayr E, Vestergaard H, Malling HJ, Jensen LB, Platzer MH, Boltz-Nitulescu G, et al. Incomplete digestion of codfish represents a risk factor for anaphylaxis in patients with allergy. Journal of Allergy and Clinical Immunology. 2007; 119: 711-717.

[45] Untersmayr E, Scholl I, Swoboda I, Beil WJ, Forster-Waldl E, Walter $\mathrm{F}$, et al. Antacid medication inhibits digestion of dietary proteins and causes food allergy: a fish allergy model in BALB/c mice. Journal of Allergy and Clinical Immunology. 2003; 112: 616-623.

[46] Untersmayr E, Jensen-Jarolim E. The role of protein digestibility and antacids on food allergy outcomes. Journal of Allergy and Clinical Immunology. 2008; 121: 1301-1308.

[47] Wu R, Yuan X, Li X, Ma N, Jiang H, Tang H, et al. The bile acidactivated retinoic acid response in dendritic cells is involved in food allergen sensitization. Allergy. 2021.

[48] Bischoff SC, Barbara G, Buurman W, Ockhuizen T, Schulzke J-D, Serino M, et al. Intestinal permeability - a new target for disease prevention and therapy. BMC Gastroenterology. 2014; 14.

[49] Gocki J, Bartuzi Z. Role of immunoglobulin G antibodies in diagnosis of food allergy. Postepy Dermatologii i Alergologii. 2016; 33: 253-256.

[50] Worm M, Reese I, Ballmer-Weber B, Beyer K, Bischoff SC, Classen $\mathrm{M}$, et al. Guidelines on the management of IgE-mediated food allergies. Allergo Journal International. 2015; 24: 256-293.

[51] Mortz CG, du Toit G, Beyer K, Bindslev-Jensen C, Brockow K, Brough HA, et al. When and how to evaluate for immediate type food allergy in children with atopic dermatitis: Allergy. 2021.

[52] Alkhateeb AF. Foods Causing Highest IgG Immune Response in Saudi Arabia. Annual Research \& Review in Biology. 2020: 115-127.

[53] Neuendorf R, Corn J, Hanes D, Bradley R. Impact of food immunoglobulin g-based elimination diet on subsequent food immunoglobulin $\mathrm{g}$ and quality of life in overweight/obese adults. journal of alternative and complementary medicine. 2018; 25: 241248.

[54] Wong KH, Horwitz R, Soffer GK. Immunoglobulin G food testing. Annals of Allergy, Asthma \& Immunology. 2021; 126: 611-612.

[55] Wells HG. Studies on the chemistry of anaphylaxis (III). Experiments with isolated proteins, especially those of the hen's egg. Journal of Infectious Diseases. 1911; 9: 147-171.

[56] Gell PGH, Harington CR, Rivers RP. The antigenic function of simple chemical compounds; production of precipitins in rabbits. British Journal of Experimental Pathology. 1946; 27: 267-286.

[57] Ishizaka K, Ishizaka T. Identification of gamma-E-Antibodies as a Carrier of Reaginic Activity. The Journal of Immunology. 1967; 99: 1187-98.

[58] Ishizaka K, Ishizaka T, Campbell DH. The biological activity of soluble antigen-antibody complexes. Journal of Experimental Medicine. 1959; 109: 127-43.

[59] Johansson SGO. The discovery of IgE. Journal of Allergy and Clinical Immunology. 2016; 137: 1671-1673.

[60] Cunningham-Rundles C, Brandeis WE, Good RA, Day NK. Milk precipitins, circulating immune complexes, and IgA deficiency. Proceedings of the National Academy of Sciences of the United States of America. 1978; 75: 3387-3389.

[61] Lefvert AK. Recurrent angioedema caused by circulating immune complexes containing antibodies against bovine proteins. International Archives of Allergy and Immunology. 1993; 102: 112-116.

[62] Volkheimer G, Garattini S, Goldin A, Hawking F, Kopin IJ. Persorption of Particles: Physiology and Pharmacology. Advances in Pharmacology. 1977; 163-87.

[63] Draper LR, Gyure LA, Hall JG, Robertson D. Effect of alcohol on the integrity of the intestinal epithelium. Gut. 1983; 24: 399-3404.

[64] Eisenmann A, Ring J, von der Helm D, Meurer M, Braun-Falco O. Allergic vasculitis caused by food allergy. Hautarzt. 1988; 39: 318321.

[65] Ferguson A, Carswell F. Precipitins to dietary proteins in serum and upper intestinal secretions of coeliac children. British Medical Journal. 1972; 1: 75-77.

[66] Olivier CE, Pinto DG, Lima RPdS, Teixeira APM, Santana JLS. Selfimposed food restriction and oral food challenges are correlated with precipitin's accuracy in the diagnosis of non-IgE-mediated food-related adulthood acute episodes of urticaria. Journal of Allergy \& Therapy. 2021; 12(8): 1-8. 


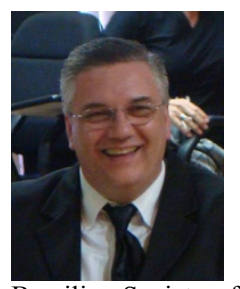

C. E. Olivier. Born in Brazil in 1963. Physician graduated from the Faculty of Medicine of the State University of Campinas (1986). Medical residency at the Faculty of Medicine of the State University of Campinas (1988). Specialist in Allergy and Immunology from the Brazilian Association of Allergy and Immunology (2011). Certified in the area of Pediatric Allergy and Immunology by the Brazilian Society of Pediatrics (2015). Specialist in Clinical Analysis by the Faculty of Health Sciences of the Methodist University of Piracicaba (2012). Doctorate (Ph.D.) in Clinical Medicine (under the guidance of Prof. Dr. Ricardo de Lima Zollner) concluded at the Department of Allergy and Immunology of the Faculty of Medicine of the State University of Campinas (2012).

$\mathrm{He}$ is the Senior Researcher of the Americana's Alergoimuno Institute (Instituto Alergoimuno de Americana). He has experience in the field of Medicine, with an emphasis on Allergy and Immunology and Clinical Analysis.

Dr. Olivier is a member of the Brazilian Association of Allergy and Immunopathology. ORCID: 0000-0001-7541-3182. His curriculum vitae can be accessed at http://lattes.cnpq.br/7035870789320492.

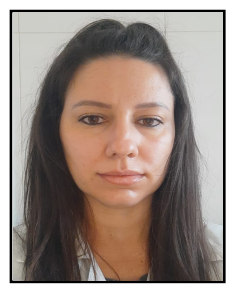

D. G. Pinto. Born in Brazil in 1985. Biomedic graduated from the Faculty of Americana (2010). She is a researcher in the Americana's Alergoimuno Institute (Instituto Alergoimuno de Americana). $\mathrm{He}$ has experience in the field of laboratory Medicine, acting mainly on the following themes: preparation of allergens and allergoids for in vivo, ex vivo, and in vitro diagnosis of allergy, leukocyte adherence inhibition tests, precipitins, and immunoblot.

ORCID: 0000-0002-4464-6669. Her curriculum vitae can be accessed at http://lattes.cnpq.br/6423437970305610.

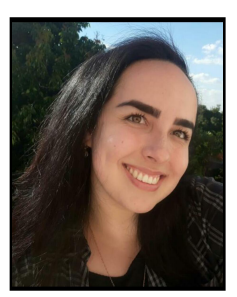

A. P. M. Teixeira Born in Brazil in 1996. Biomedic graduated from the Faculty of Americana (2018).

Former trainee (2018) from the Americana's Alergoimuno Institute (Instituto Alergoimuno de Americana). He was trained in the field of laboratory Medicine, acting mainly on the following themes: preparation of allergens and allergoids for in vivo, ex vivo, and in vitro diagnosis of allergy, skin-allergic tests, leukocyte adherence inhibition tests, precipitins, and immunoblot. ORCID: 0000-0001-5140-9285

Her curriculum vitae can be accessed at http://lattes.cnpq.br/9364659098398568.

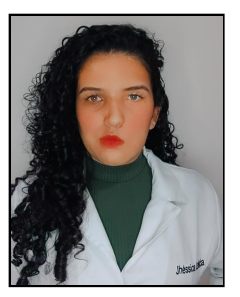

J. L. S. Santana. Born in Brazil in 1997. Undergraduate Biomedic from the Faculty of Americana (2021).

Former trainee (2020/2021) from the Americana's Alergoimuno Institute (Instituto Alergoimuno de Americana). He was trained in the field of laboratory Medicine, acting mainly on the following themes: preparation of allergens and allergoids for in vivo, ex vivo, and in vitro diagnosis of allergy, skin-allergic tests, leukocyte adherence inhib.ition tests, precipitins, and immunoblot. ORCID 000-0001-8519-127X.

Her curriculum vitae can be accessed at http://lattes.cnpq.br/4811507530904182.

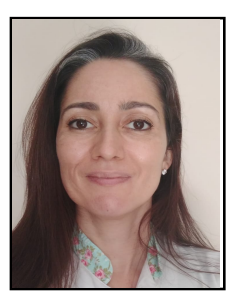

R. A. P. Gonçalves dos Santos. Born in Brazil in 1976. Nurse graduated from the Anhanguera Santa Barbara Faculty (2016).

She is a researcher in the Americana's Alergoimuno Institute (Instituto Alergoimuno de Americana). He has experience in the field of diagnostic Medicine, acting mainly on in vivo diagnosis of allergy. ORCID: 0000-0001-6469-8207.

http://lattes.cnpq.br/2757001223214460.

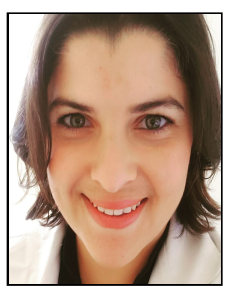

R. P. dos Santos Lima. Born in Brazil in 1985. Biomedic graduated from the Anhanguera Santa Barbara Faculty (2015).

She was a researcher in the Americana's Alergoimuno Institute (Instituto Alergoimuno de Americana). He has experience in the field of laboratory Medicine, acting mainly on the following themes: preparation of allergens and allergoids for in vivo, ex vivo, and in vitro diagnosis of allergy.

ORCID: 0000-0003-4845-8822.

Her curriculum vitae can be accessed at http://lattes.cnpq.br/2757001223214460. 